\title{
Impacts of hydroelectric dams on alluvial riparian plant communities in eastern Brazilian Amazonian
}

\author{
LEANDRO VALLE FERREIRA ${ }^{1}$, DENISE A. CUNHA ${ }^{1}$, PRISCILLA P. CHAVES ${ }^{1}$, \\ DARLEY C.L. MATOS ${ }^{1}$ and PIA PAROLIN ${ }^{2}$ \\ ${ }^{1}$ Museu Paraense Emílio Goeldi, Coordenação de Botânica, \\ Avenida Perimetral, 1901, Bairro Terra Firme, 66077-530 Belém, PA, Brasil \\ ${ }^{2}$ Biodiversität, Evolution und Ökologie der Pflanzen/BEE, Biozentrum Klein Flottbek und Botanischer Garten, \\ Universität Hamburg, Ohnhorststr., 18, 22609 Hamburg, Deutschland
}

Manuscript received on October 31, 2011; accepted for publication on May 15, 2012

\begin{abstract}
The major rivers of the Amazon River basin and their biota are threatened by the planned construction of large hydroelectric dams that are expected to have strong impacts on floodplain plant communities. The present study presents forest inventories from three floodplain sites colonized by alluvial riparian vegetation in the Tapajós, Xingu and Tocantins River basins in eastern Amazonian. Results indicate that tree species of the highly specialized alluvial riparian vegetation are clearly distinct among the three river basins, although they are not very distinct from each other and environmental constraints are very similar. With only 6 of 74 species occurring in all three inventories, most tree and shrub species are restricted to only one of the rivers, indicating a high degree of local distribution. Different species occupy similar environmental niches, making these fragile riparian formations highly valuable. Conservation plans must consider species complementarily when decisions are made on where to place floodplain forest conservation units to avoid the irreversible loss of unique alluvial riparian vegetation biodiversity.
\end{abstract}

Key words: Amazon River basin, biodiversity loss, floodplain forest, hydroelectric dams.

\section{INTRODUCTION}

In the Brazilian Amazon River basin, two huge hydroelectric dams are currently in operation: Balbina, in Amazonas state, and Tucuruí, Pará state. Their construction caused the flooding of thousands of square kilometers of forested area (Fearnside 1995). At the moment, two large hydroelectric dams are under construction: Jirau and Santo Antônio on the Madeira River, in Rondônia, and the construction of the Belo Monte hydroelectric dam on the Xingu River, in Pará state, began in the

Correspondence to: Leandro Valle Ferreira

E-mail:1vferreira@museu-goeldi.br second semester of 2011. The planning of six new hydroelectric dams is now in progress. These are for the Tapajós and Jamanxin Rivers in Pará state, totaling $2,600 \mathrm{~km}^{2}$ of flooded area and affecting directly many protected conservation areas and indigenous lands (Tundisi 2007).

The hydroelectric dams planned for the Xingu, Tapajós and Jamanxim Rivers are the focus of an intensive controversy due to the vast areas they will flood and the magnitude of their expected impacts.

In their natural state, large tracts of floodplain forests along these rivers are subject to periodic 
and predictable periods of annual flooding caused by cyclical fluctuations in water levels linked to precipitation throughout the Amazon basin (Junk 1989). The organisms colonizing Amazonian floodplain forests exhibit manifold adaptations against waterlogging and submergence (Junk 1989, Adis and Messner 1997, Parolin et al. 2004), including morphological, physiological, and behavioral adaptations. Efficient mechanisms of fixation to substrates allow some organisms to withstand the mechanical strains brought about by flooding and high water velocity mainly in the draining period (Junk 1989, Parolin 2001). Other organisms exhibit vertical migration on trees.

There are two main types of floodplain vegetation in the Tapajós, Xingu and Tocantins River basins in eastern Amazonian, dense ombrophilous flood forest (Salomão et al. 2007) and alluvial riparian vegetation (Veloso et al. 1991). These vegetations colonize mainly sandy and rocky islands along river margins or on islands in the river beds (Veloso et al. 1991).

The particularity of these vegetation formations is that they occur on nutrient-poor rocky formations that belong to the oldest of the world, dating back to more than a billion years (Silva et al. 1974). These formations are highly specialized climax communities adapted to a lack of soil nutrients; long periods of inundation and strong water currents during the high water period, and they are sensitive to habitat alterations (Cunha and Ferreira 2012).

In the alluvial riparian vegetation, the forest structure is low, formed mostly by shrubs and small trees that do not form a close canopy. Emergent species reach only $15 \mathrm{~m}$ in height. Species richness is very low compared to other types of Amazonian floodplain forests (Wittmann et al. 2004, 2010, Salomão et al. 2007).

The construction of hydroelectric dams in Amazonian will cause the flooding of extensive areas due to the formation of reservoirs, resulting in huge losses of forested areas that are the habitats of many species of plants and animals (Alho 2011). Artificial alterations of the hydrological cycle and the drowning of alluvial riparian vegetation can be expected to influence growth, survival and species composition of these forests and have a major negative impact on their functions and conservation (Ferreira et al. 2010). This outcome can already be observed in the reservoir of the Tucuruí Dam on the lower Tocantins River which is responsible for a great loss of habitat of natural vegetation cover with significant decrease in species richness, and changes in species composition (Veloso et al. 1991).

In order to formulate management and conservation plans, as well as environmental compensation measures, local alluvial riparian vegetation in areas to be flooded should be inventoried and their status determined. The objective of this study is to assess the and compare species richness, alpha and beta diversity, density and composition of the riparian plant vegetation of the Tapajós, Xingu and Tocantins River basins in areas that will be heavily influenced by projected hydroelectric dams in Pará state in the Brazilian Amazon, as well as to suggest mitigatory measures for environmental compensation. The key focus is on a comparison of riparian forest in three adjacent river systems with similar environmental constraints to the vegetation, namely poor soils, rocky substrates, and periodic recurring flooding. We analyzed species composition and complementarily over short distances between the river basins.

\section{MATERIALS AND METHODS}

\section{STUDY AREA}

Forest inventories were carried out in the areas near the existing Tucuruí hydroelectric dam, on the Tocantins River, and two projected hydroelectric plants, Belo Monte on the Xingu River and São Luiz do Tapajós on the Tapajós River, all three in Pará state (Figure 1). Sampled sites are 200 to $400 \mathrm{~km}$ apart, in the three river basins. 


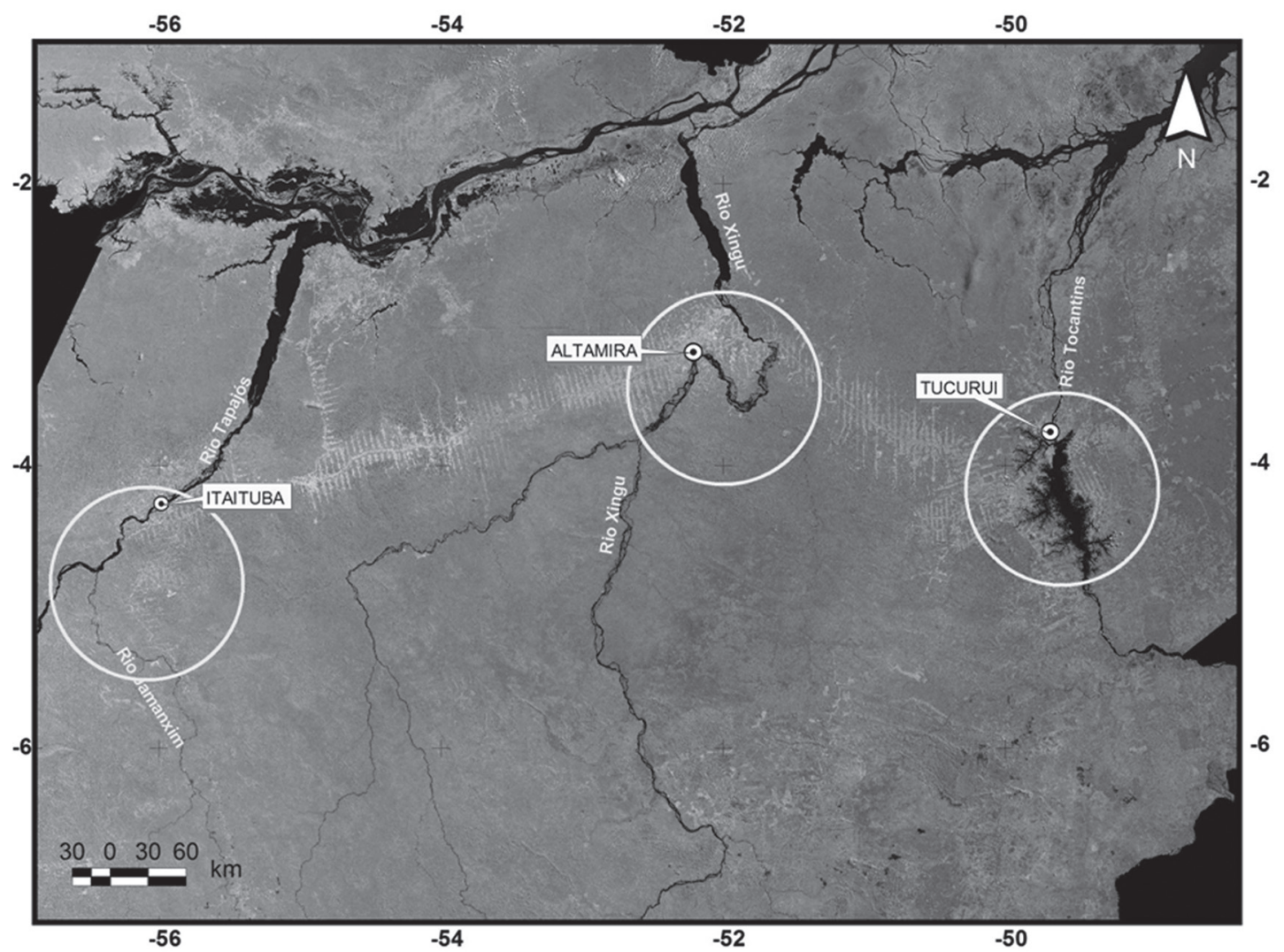

Figure 1 - Satellite image of the Tapajós, Xingu, and Tocantins Rivers (from west to east), showing the locations of the Tucuruí dam on the Tocantins River and future dams sites on the Xingu and Tapajós Rivers.

\section{DATA COLLECTION}

The vegetation was inventoried on 130 islands of different sizes, ranging from 0.1 to 10.0 hectares. All were colonized by alluvial riparian vegetation (Veloso et al. 1991). Surveys were carried out between September and November, 2010, during the low water period when this type of vegetation is not flooded (Figure 2).

In three sampled river basins 130 plots of $5 \times 20$ meters were established on the islands, varying from 30 plots on the Tocantins River to 50 plots on the Tapajós and Xingu Rivers. In each plot all trees and shrubs with DBH (diameter at breast height) greater than or equal to $1 \mathrm{~cm}$ were measured and the individuals determined to species level. Height of trees was estimated. Fertile botanic material was collected for all species and deposited in the João Murça Pires Herbarium of the Museu Paraense Emílio Goeldi (MPEG), in Belém, Brazil.

\section{DATA ANALYSIS}

Floristic and phytosociological data were analyzed with the Mata Nativa program (Cientec 2006). To test the sufficiency of plots the collector's curve was used (Cain 1956).

Differences in species richness and diversity (dependent variables) among the three rivers (factors) were tested using simple analysis of variance and the Tukey's test, in order to detect differences in the dependent variables in relation to the factors (Zar 2010). Species similarity was analyzed with the Sørensen similarity index (Krebs 1999), through an analysis of ordinance (nonmetric multidimensional scheduling, NMS), using 

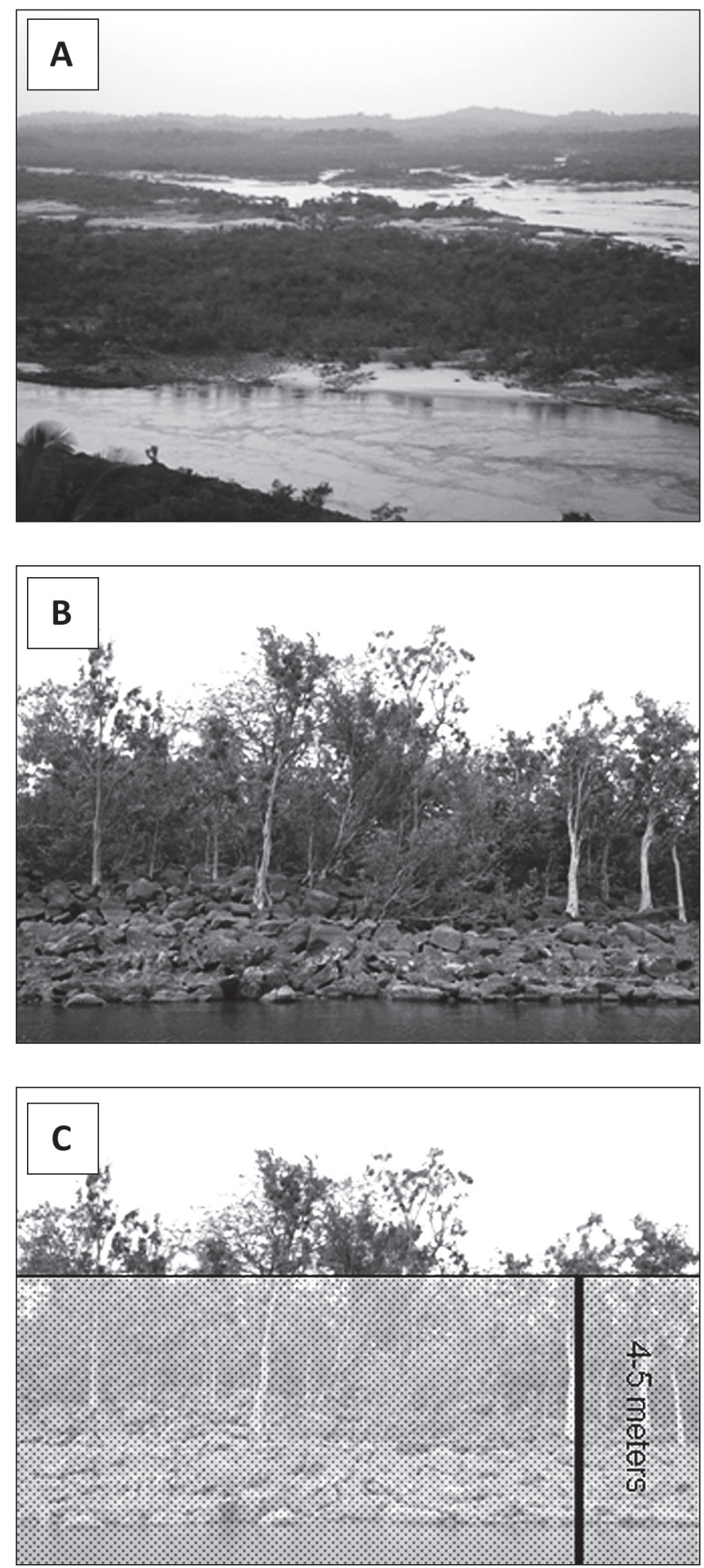

Figure 2 - Typical alluvial riparian vegetation on the Xingu River (A) covering whole islands e showing rocky substrate during low water (B), with an indication of flood period water level (C). (Photographs by Leandro Ferreira, 2010). 
Euclidean distance as measure for species similarity and next neighbor to test for links between the plots (Mccune and Brace 2002).

\section{RESULTS}

\section{SAMPLING EFFICIENCY}

The collector's curves reached a stable level in the three inventoried sites, indicating that sampling effort for each area was sufficient to determine local species richness (Figure 3).
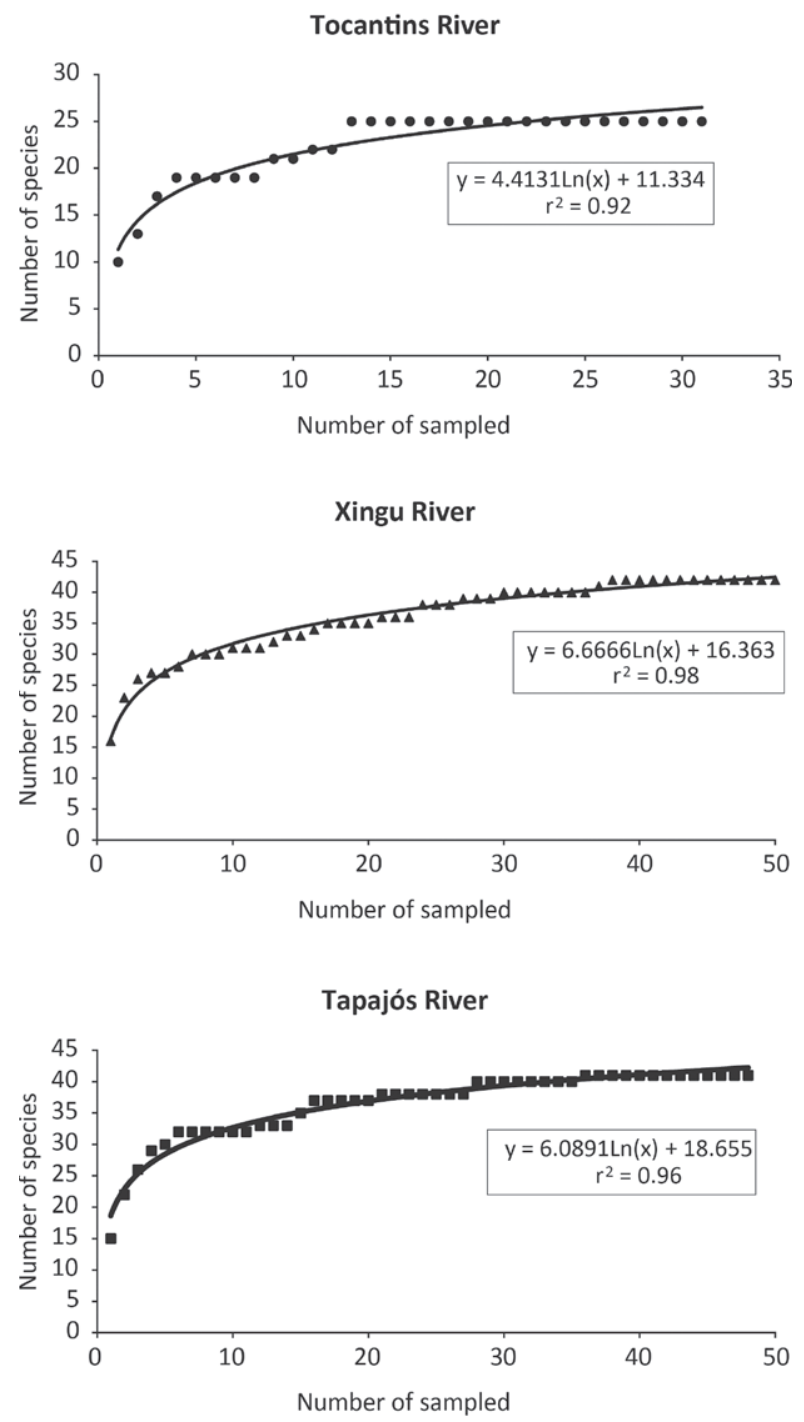

Figure 3 - Collector's curves for the three sample sites of alluvial riparian vegetation on the Tapajós, Xingu, and Tocantins Rivers.
SPECIES RICHNESS

A total of 4,823 individuals of shrubs and trees were sampled, belonging to 39 species on the Tapajós River, 42 species on the Xingu River, and 25 species on the Tocantins River. These were clear differences in species richness and diversity among the three sites, these being significantly higher in plots on the Xingu River compared to those on the Tapajós and Tocantins Rivers which were not significantly different from one another (Figure 4).
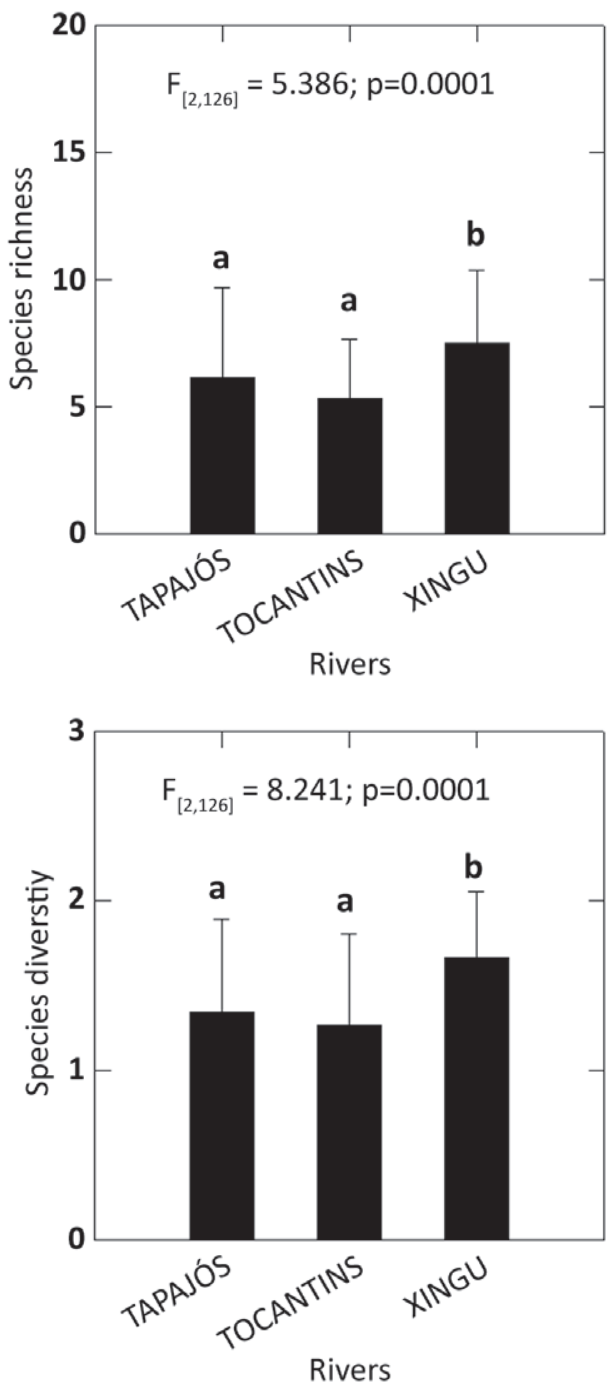

Figure 4 - Species richness and diversity in the three sites with alluvial riparian vegetation on the Tapajós, Xingu, and Tocantins Rivers (different letters indicate significant differences). 


\section{SPECIES SIMILARITY AND SPECIES COMPOSITION}

Ordinance analysis showed a clear separation of species composition among the alluvial riparian vegetation of the three rivers (Figure 5). The plant communities of the three river basins showed a geographic pattern in a west to east direction, of complementarities in species composition.

Only 6 species $(12.2 \%)$ of the total of 74 species were common to all three sampling sites
(Table I). Only a few species showed the highest relative densities of the sampled individuals on the Tapajós, Xingu, and Tocantins Rivers (Table I). This indicates the dominance of a group of few species in the three rivers sampled, showing that the alluvial riparian vegetation is characterized by low species richness associated with a great number of rare species and a low frequency of species common to all three rivers.

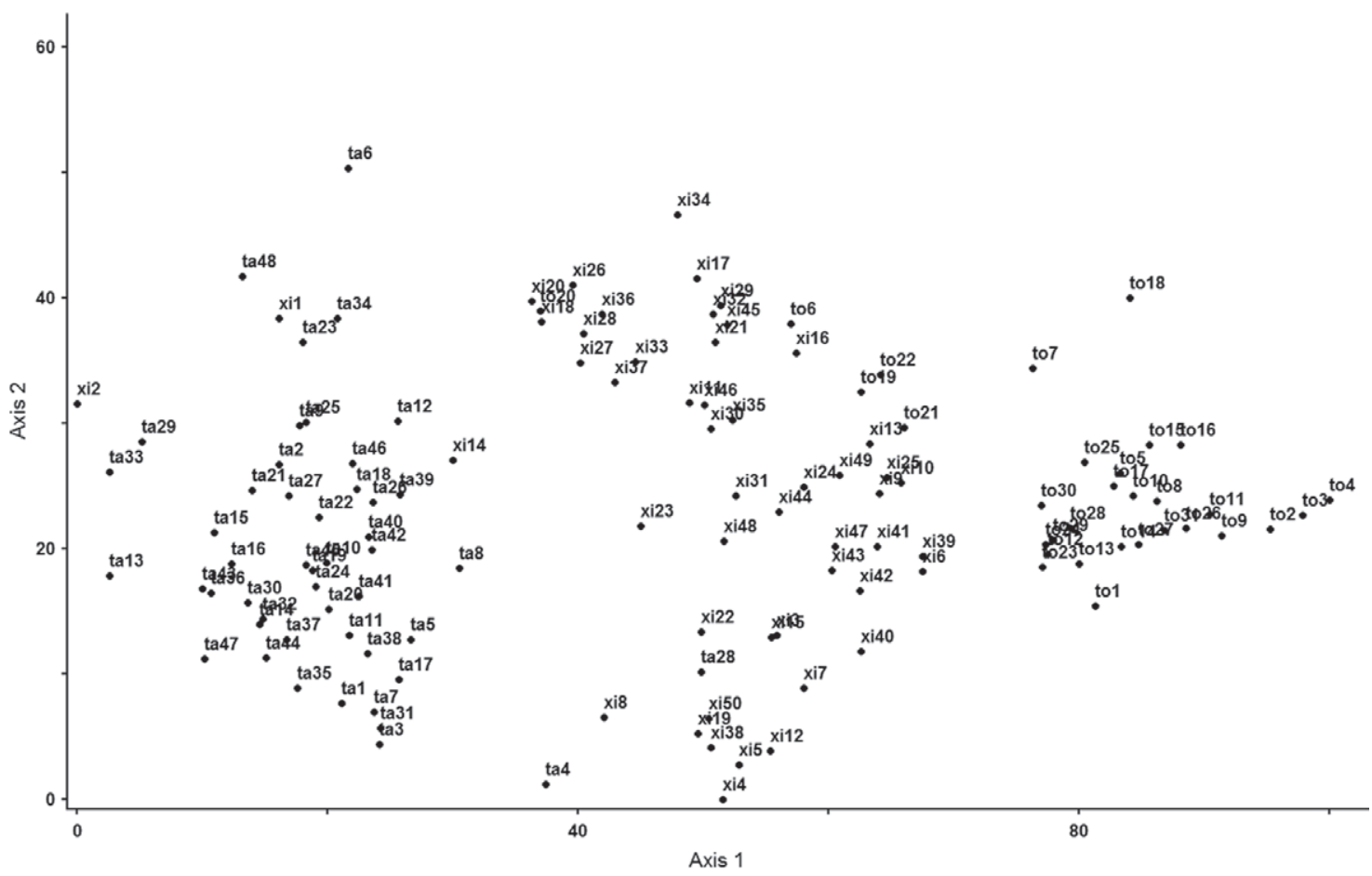

Figure 5 - Multidimensional scaling analysis, showing grouping of plots based on speciescomposition in the three sample sites from west to east of alluvial riparian vegetation on the Tapajós (ta), Xingu (xi) and Tocantins (to) Rivers.

TABLE I

Vegetation (shrubs and trees) of alluvial riparian vegetation on the Tapajós, Xingu, and Tocantins Rivers.

\begin{tabular}{llccc|ccc|ccc}
\hline & & \multicolumn{3}{c|}{ Tapajós River } & \multicolumn{3}{c|}{ Xingu River } & \multicolumn{3}{c}{ Tocantins River } \\
\hline & Scientific name & RDo & RD & RF & RDo & RD & RF & RDo & RD & RF \\
\hline 1 & Acosmium nitens & 12.8 & 2 & 4.4 & 20 & 2.9 & 6.4 & & & \\
2 & Aeschynomene brevifolia & & & & & & & 1.5 & 4.1 & 3.6 \\
3 & Alchornea fluviatilis & & & & & & & 6.9 & 4.2 & 5.5 \\
4 & Amajoua guianensis & 0.2 & 0.3 & 0.3 & & & & & & \\
5 & Anisomeres preslii & 0.5 & 1 & 3.4 & & & & & & \\
\hline
\end{tabular}

RDo: relative dominance; RD: relative density and RF: relative frequency; Bold: species occurring in all three sampling sites. 
TABLE I (continuation)

\begin{tabular}{|c|c|c|c|c|c|c|c|c|c|c|}
\hline & \multirow[b]{2}{*}{ Scientific name } & \multicolumn{3}{|c|}{ Tapajós River } & \multicolumn{3}{|c|}{ Xingu River } & \multicolumn{3}{|c|}{ Tocantins River } \\
\hline & & RDo & $\mathrm{RD}$ & $\mathrm{RF}$ & RDo & $\mathrm{RD}$ & $\mathrm{RF}$ & RDo & $\mathrm{RD}$ & $\mathrm{RF}$ \\
\hline 6 & Astrocaryum jauari & & & & 0.2 & 0.1 & 0.3 & 5.7 & 0.5 & 1.2 \\
\hline 7 & Basanacantha armata & 0 & 0.1 & 0.3 & & & & & & \\
\hline 8 & Buchenavia grandis & & & & 0.1 & 0.6 & 0.8 & & & \\
\hline 9 & Buchenavia oxycarpa & 0 & 0.1 & 0.3 & 6.2 & 5.4 & 6.2 & & & \\
\hline 10 & Calophyllum brasiliense & & & & 1.4 & 0.2 & 0.3 & & & \\
\hline 11 & Campsiandra comosa & 0.4 & 0.3 & 1.4 & 9.6 & 8.5 & 8.6 & 1.6 & 0.9 & 1.2 \\
\hline 12 & Clitoria amazonum & & & & 0 & 0.1 & 0.3 & & & \\
\hline 13 & Clitoria racemosa & 1.2 & 1.4 & 3.7 & & & & & & \\
\hline 14 & Coccoloba acuminata & & & & 0 & 0.2 & 0.3 & & & \\
\hline 15 & Coccoloba pichuna & 0 & 0.1 & 0.3 & & & & & & \\
\hline 16 & Couepia cataractae & 14.2 & 24.9 & 13.3 & 3.1 & 10.3 & 9.4 & 2.2 & 2.9 & 6.1 \\
\hline 17 & Conepia paraensis & 2 & 1.3 & 2.4 & & & & 2.8 & 1.1 & 1.2 \\
\hline 18 & Crataeva benthamii & & & & 0.3 & 1.2 & 1.6 & & & \\
\hline 19 & Dalbergia inundata & & & & 0.1 & 0.9 & 1.1 & & & \\
\hline 20 & Eugenia biflora & & & & 0 & 0.1 & 0.3 & & & \\
\hline 21 & Eugenia brachipoda & & & & & & & 0.2 & 0.5 & 1.2 \\
\hline 22 & Eugenia flavescens & 0 & 0.2 & 0.7 & & & & & & \\
\hline 23 & Eugenia inundata & & & & 0 & 0.1 & 0.3 & 0.9 & 3.2 & 2.4 \\
\hline 24 & Eugenia patens & & & & 0.8 & 3.9 & 3.5 & & & \\
\hline 25 & Gaya scopulorum & 0.4 & 3.5 & 3.4 & 0.1 & 1 & 0.8 & 3.2 & 12.5 & 11.5 \\
\hline 26 & Genipa spruceana & 0.5 & 0.2 & 0.3 & 1.3 & 0.6 & 1.9 & & & \\
\hline 27 & Hidrochoria corimbosa & & & & & & & 0 & 0.1 & 0.6 \\
\hline 28 & Licania apetala & 0.4 & 0.2 & 0.7 & $\mathbf{0}$ & 0.1 & 0.3 & 10 & 1.3 & 1.2 \\
\hline 29 & Licania leptostachya & & & & 7.4 & 2.6 & 5.4 & & & \\
\hline 30 & Mabea caudata & 5.5 & 5.2 & 5.4 & 0 & 0.2 & 0.3 & & & \\
\hline 31 & Machaerium aristulatum & & & & 1.2 & 0.3 & 0.8 & 0.5 & 1 & 1.8 \\
\hline 32 & Macrolobium sp. & & & & 0.3 & 0.1 & 0.3 & & & \\
\hline 33 & Malouetia tamaquarina & 0.1 & 0.1 & 0.3 & & & & & & \\
\hline 34 & Maripa reticulata & & & & 0 & 0.1 & 0.3 & & & \\
\hline 35 & Mascagnia benthamiana & & & & 0 & 0.2 & 0.3 & & & \\
\hline 36 & Maytenus ebenifolia & 0 & 0.3 & 1.4 & & & & & & \\
\hline 37 & Mimosa sensitiva & & & & & & & 0.1 & 0.5 & 4.2 \\
\hline 38 & Myrcia inundata & 0 & 0.3 & 0.3 & & & & & & \\
\hline 39 & Myrcia phalax & 0.7 & 0.7 & 2 & & & & & & \\
\hline 40 & Myrcia sp & 0.9 & 0.3 & 0.7 & & & & & & \\
\hline 41 & Myrciaria floribunda & 23.1 & 30.7 & 16.7 & 6 & 22.1 & 10 & 7.9 & 12.6 & 10.3 \\
\hline 42 & Ouratea racemiformis & 0.8 & 2 & 2.4 & & & & & & \\
\hline 43 & Ouratea salicifolia & 0.1 & 0.4 & 1.4 & & & & & & \\
\hline
\end{tabular}

RDo: relative dominance; RD: relative density and RF: relative frequency; Bold: species occurring in all three sampling sites. 
TABLE I (continuation)

\begin{tabular}{|c|c|c|c|c|c|c|c|c|c|c|}
\hline & \multirow[b]{2}{*}{ Scientific name } & \multicolumn{3}{|c|}{ Tapajós River } & \multicolumn{3}{|c|}{ Xingu River } & \multicolumn{3}{|c|}{ Tocantins River } \\
\hline & & RDo & $\mathrm{RD}$ & RF & RDo & $\mathrm{RD}$ & $\mathrm{RF}$ & RDo & $\mathrm{RD}$ & RF \\
\hline 44 & Palicourea quadrifolia & & & & 0 & 0.1 & 0.3 & & & \\
\hline 45 & Passiflora nitida & 0 & 0.1 & 0.3 & & & & & & \\
\hline 46 & Piranhea trifoliata & 14.4 & 1.3 & 4.4 & 5.9 & 1.5 & 2.4 & & & \\
\hline 47 & Pouteria procera & & & & 0.3 & 0.2 & 0.3 & & & \\
\hline 48 & Psidium acuminatum & & & & & & & 33.8 & 23.2 & 15.2 \\
\hline 49 & Psidium guianense & & & & 0 & 0.1 & 0.3 & & & \\
\hline 50 & Psidium paraense & 0.1 & 0.2 & 0.3 & 2.1 & 5.9 & 3.7 & & & \\
\hline 51 & Psidium sessilis & & & & & & & 0 & 0.1 & 0.6 \\
\hline 52 & Psidium verrucosum & 0.2 & 0.4 & 1.4 & 0 & 0.3 & 0.5 & 1.3 & 1.1 & 3.6 \\
\hline 53 & Pterocarpus amazonicus & & & & 1.1 & 0.8 & 1.6 & 8.3 & 4 & 4.2 \\
\hline 54 & Retiniphyllum schomburgkii & & & & 0 & 0.1 & 0.3 & & & \\
\hline 55 & Robinia sp. & 0.2 & 0.7 & 2 & 0.1 & 0.3 & 1.3 & 0.4 & 0.5 & 2.4 \\
\hline 56 & Rotula pohlii & & & & 0 & 0.1 & 0.3 & 3.2 & 20.7 & 11.5 \\
\hline 57 & Rudgea cornifolia & 0 & 0.2 & 0.7 & & & & & & \\
\hline 58 & Ruprechtia brachysepala & & & & 1.2 & 2.1 & 4 & 0.3 & 0.6 & 1.8 \\
\hline 59 & Ryania angustifolia & 0.1 & 0.3 & 0.3 & & & & & & \\
\hline 60 & Sapium duckei & & & & 0 & 0.1 & 0.3 & & & \\
\hline 61 & Sarcaulus brasiliensis & & & & 0 & 0.1 & 0.3 & & & \\
\hline 62 & Simaba guianensis & 0.4 & 0.3 & 1 & 1.2 & 0.3 & 1.3 & & & \\
\hline 63 & Simaba polyphylla & & & & & & & 7.4 & 2.6 & 5.5 \\
\hline 64 & Stachyarrhenia spicata & 1.9 & 3.5 & 4.4 & & & & & & \\
\hline 65 & Swartzia cf. laurifolia & 0.8 & 0.2 & 0.7 & & & & & & \\
\hline 66 & Swartzia leptopetala & & & & 22.8 & 9.4 & 7 & & & \\
\hline 67 & Symmeria paniculata & 0 & 0.2 & 0.7 & 0.3 & 2.1 & 4 & 0.5 & 0.5 & 1.2 \\
\hline 68 & Tocoyena brasiliensis & 0 & 0.1 & 0.3 & & & & & & \\
\hline 69 & Trichilia singularis & 0.1 & 0.4 & 1.7 & & & & & & \\
\hline 70 & Vasivaea alchorneoides & 0 & 0.2 & 0.7 & & & & & & \\
\hline 71 & Vasivaea loranthoides & & & & & & & 0 & 0.1 & 0.6 \\
\hline 72 & Vitex cf. duckei & & & & 6.5 & 12.8 & 9.6 & & & \\
\hline 73 & Vitex cymosa & 5.6 & 0.7 & 2.4 & & & & & & \\
\hline 74 & Zygia cauliflora & 12.4 & 15.9 & 12.6 & 0.5 & 2.3 & 3.2 & 1.3 & 1.5 & 1.2 \\
\hline
\end{tabular}

RDo: relative dominance; RD: relative density and RF: relative frequency; Bold: species occurring in all three sampling sites.

\section{DISCUSSION}

Most plant species found in the alluvial riparian formations of this study are rare at local level and clearly restricted to one of the three sampled river basins. Only six species were common to the plots in all three river systems. Even among the most dominant species, only two were common to all three sampling sites. It is important to emphasize that in sites with high environmental stresses, such as rocky substrates or periodically waterlogged or submerged sites, the dominance of few species is typical. Not so many species are expected to be adapted to such harsh environmental constraints. Limiting environmental factors of the pioneering 
formations include periodical fluctuations of river levels and low nutrient availability on the rocky substrates of the islands, as well as mechanical stresses related to river currents during flooding (Salomão et al. 2007, Cunha and Ferreira 2012). However, as suggested by these data, suggest as well as data from central Amazonian floodplain forests (Ferreira 1997, Parolin et al. 2004), a range of species are adapted and can fill interchangeable niches within these plant communities. This leads to a high level of endemism with both high species richness and high local variability.

Observed differences in species richness, diversity and composition in alluvial riparian vegetation on the Tapajós, Xingu and Tocantins Rivers demonstrate that most species are restricted to only one of the rivers, an indication of high local rarity. Although the environmental constraints are almost identical, only 6 of 74 species occurred in all three inventoried sites. This indicates the filling of this niche with many different species having similar functional traits. Therefore, it is important for conservation actions to preserve these locally distributed species. Environmental compensation programs for hydroelectric dams should protect the riparian areas to which these plants are adopted.

Whether already implanted or in the future, all planning for hydroelectric dams has to consider that many plant species occurring on Amazonian river systems are both rare and to only one river basin. There is a high complementarily of the total set of species, with alternative designs of equal fitness occurring in similar environments, which make these fragile ecosystems of pioneering formations so valuable. As is typical for tropical forests in Amazonian, the majority of species are rare and thus the forests are characterized by high species richness associated with low abundances.

Many floristic studies carried out in the Amazon basin characterize a specific type of vegetation, its structure and species abundance, but these data are not generally compared with the total set of species of the community (Lyons 2005). By comparing three similar ecosystems, all within just 200 to 400 $\mathrm{km}$, we show that the assayed plant communities can differ in species composition, although they are composed of similar functional types adapted to rocky substrate and comprising typical pioneering formations. Attention must be given to the serious problem of conservation of the regional flora, with focus on the preservation of plant communities.

The construction of hydroelectric dams with flooding and destruction of huge areas will thus most likely result in the strong reduction of species diversity and richness of the alluvial riparian vegetation in the Tapajós, Xingu and Tocantins River basins, as well as in other Amazonian localities where other hydroelectric dams are planned. This knowledge is not new (Junk 1987), but little has been done to avoid foreseen impacts.

Several studies have demonstrated that one of the basic factors maintaining ecosystem functions and biotic diversity in Amazonian floodplains is the periodic fluctuation of river levels, causing a natural alternation of flooded and un-flooded periods (Junk 1989). Ferreira and Parolin (2007) demonstrated that tree reproduction and establishment in central Amazonian floodplains are associated with river level fluctuations and largely depend upon them. Other studies showed that fish species also depend on the connectivity among water bodies and on annual flooding periodicity for their great migrations and reproductive cycles (Barthem et al. 1991, Barthem and Goulding 1997). River seasonal hydrological flux is also important for freshwater turtles, wild mammals both terrestrial and aquatic (Alho 2011).

Large Amazonian dams, now in various phases of building, will cause environmental impacts on plant communities. Such as the loss of vegetation types, disappearance of specific habitats, and loss or migration of important faunal elements that have key functions for pollination and plant dispersal. Besides of the loss of single species with unknown 
potentials, changes in vegetation cover may modify the hydrologic patterns, the aeration of the rhizosphere and microclimatic patterns. Increased tree mortality will be caused by new flooding patterns imposed by water level regulation of the dams, and to a large extent by the elimination of an un-flooded period on which the vegetation depends for growth and seedling establishment.

The reservoir of the Tucuruí dam already caused extensive habitat loss for alluvial riparian vegetation of the Tocantins River, reflected in lower species richness and diversity in comparison with still pristine formations on the Xingu and Tapajós Rivers that are yet unaffected by the implantation of the planned hydroelectric dams. Some $90 \%$ of the riparian habitats for pioneer formations on the Xingu River will be affected by construction of the Belo Monte hydroelectric dam (Cunha and Ferreira 2012). The same will occur with alluvial riparian vegetation on the Tapajós and Jamanxin Rivers with the construction of five projected hydroelectric dams.

This study emphasizes that, in the analyzed areas, rare species will be threatened by the construction of hydroelectric dams. Political decisions concerning measures for environmental compensation of the hydroelectric enterprises must be specific to each of the hydrographic basins. Alluvial riparian vegetation of Amazonian river systems will soon suffer the impacts of new giant hydroelectric dams. In order to protect these plant communities, conservation units must consider the principle of complementarily which aims at increasing the species diversity in reserves while minimizing redundancy or species repetition (Vane-Wright et al. 1991, Pressey et al. 1993). The principle of complementarily states that areas with different attributes (species, habitats and landscapes) should be chosen for reserves and not areas that duplicate the same attributes (Anacleto et al. 2005). In the alluvial riparian vegetation of Amazonian rivers, where most species are restricted to a single hydrographic basin, the most important attribute for conservation is complementarily of species composition. If this is not considered as a conservation strategy, original biodiversity will be lost irreversibly, without the possibility for compensation at other locations.

\section{ACKNOWLEDGMENTS}

The Brazilian Ministry of Science, Technology and Innovation helped finance this study through the Network for Amazon Environmental Modeling (Geoma), the Museu Paraense Emílio Goeldi provided support, Mr. Luiz Carlos Batista Lobato assisted in the collection and identification of plants. Dr. William Overal and Patrick Meir kindly reviewed the manuscript.

\section{RESUMO}

Os principais rios da bacia Amazônia e sua biota estão ameaçados pelos planos de construção de grandes usinas hidrelétricas que poderá causar fortes impactos nas comunidades vegetais das áreas alagadas. O objetivo desse estudo é apresentar os inventários botânicos em três áreas de vegetações inundadas dos rios Tocantins, Xingu e Tapajós no leste da Amazônia. Os resultados do estudo mostram uma flora altamente especializada das vegetações inundadas, claramente distintas entre as três bacias, embora os ambientes entre as bacias dos rios não sejam distintos entre si e as condições ambientais muito semelhantes. Somente 6 das 74 espécies ocorreram nos três inventários, sendo a maioria das arvores e arbustos restritos a um dos rios, indicando um alto grau de distribuição local. Espécies diferentes ocupam nichos ambientais semelhantes, mostrando alto valor de conservação dessas formações vegetais. Os planos de conservação devem considerar a complementaridade das espécies nas tomadas de decisões de onde colocar as unidades de conservação nesses nas florestas inundadas a fim de evitar de forma irreversível a perda da biodiversidade.

Palavras-chave: Amazônia, perda de biodiversidade, florestas inundáveis, usinas hidrelétricas. 


\section{REFERENCES}

AdIS J AND Messner B. 1997. Adaptations to life under water: Tiger beetles and millipedes. In: Junk WJ (Ed), The Central Amazon floodplain: Ecology of a pulsing system, Ecological Studies 126, Springer Verlag, Heidelberg, p. 319-330.

ALHO CJR. 2011. Environmental effects of hydropower reservoirs on wild mammals and freshwater turtles in Amazonian: a review. Oecol Aust 15(3): 593-604.

ANACleto TCS, Ferreira AA, Diniz JAF AND Ferreira LG. 2005. Seleção de áreas de interesse ecológico através de sensoriamento remoto e de otimização matemática: um estudo de caso no município de Cocalinho, MT. Act Amaz 35: 437-443.

BARTHEM RB AND GOULDING M. 1997. The catfish connection: ecology, migration, and conservation of Amazon predators, Biology and Resource Management in the Tropics Series, New York: Columbia Press, 144 p.

BARThem RB, Ribeiro MCLB AND Petrere JR M. 1991. Life strategies of some long distance migratory catfish in relation to hydroelextric dams in the Amazon Basin. Biol Conserv 55: 339-345.

CAIN SA. 1956. Application of some phytossociological tecniques to Brazilien forest. Am J Bot 43: 911-941.

CIENTEC. 2006. Consultoria e Desenvolvimento de Sistemas. Mata nativa 2: Manual do usuário, Viçosa: Cientec, p. 295. Available from: http://www.matanativa.com.br/

CunHa DC AND FERREIRA LV. 2012. Impacts from the Belo Monte. Hydroelectric construction on the pioneer formations of the Xingu River, Pará. Brazilian Journal of Botany 35(2): 159-167.

FEARNSIDE PM. 1995. Hydroelectric dams in the Brazilian Amazon as Sources of "greenhouse" gases. Enviro Conser 22: 7-19.

FERREIRA LV. 1997. Effects of the duration of flooding on species richness and floristic composition in three hectares in the Jaú National Park in floodplain forests in central Amazonia. Biodivers Conserv 6: 1353-1363.

FERREIRA LV AND PAROLIN P. 2007. Tree phenology in central Amazonian floodplain forests: effects of water level fluctuation and precipitation at community and population level. Pesq Bot 1: 139-156.

Ferreira LV, PARolin P AND ALmeIda SS. 2010. Amazonian white- and blackwater floodplain forests in Brazil: large differences on a small scale. Ecotropica 16: 31-41.

JUNK WJ. 1987. Impactos ecológicos das represas hidrelétricas na bacia amazônica brasileira. Tübinger Geographische Studien 95: 367-385.

JUNK WJ. 1989. Flood tolerance and tree distribution in Central Amazonian floodplains. In: Nielsen LB et al. (Eds), Tropical forests: Botanical dynamics, speciation and diversity, Academic Press London, p. 47-64.
KREBS CJ. 1999. Ecological methodology. Addison-Wesley Educational Publishers, Menlo Park, 607 p.

LyONS KG. 2005. Rare species and ecosystem functioning. Conserv Biol 19: 1019-1024.

McCune B AND BRACE JB. 2002. Analysis of ecological communities. MjM Software Design, Gleneden Beach, Oregon, USA.

PAROLIN P. 2001. Morphological and physiological adjustments to waterlogging and drought in seedlings of Amazonian floodplain trees. Oecol 128: 326-335.

Parolin P, De Simone O, HaAke K, Waldhoff D, Rottenberger S, KuhN U, Kesselmeier J, Schmit W, PiedAdE MTF AND JunK WJ. 2004. Central Amazon floodplain forests: tree survival in a pulsing system. The Bot Rev 70: 357-380.

Pressey RL, Humphries CJ, Margules CR, VANE-Wright RI AND WiLLIAMS PH. 1993. Beyond opportunism: key principles for systematic reserve selection. Tree 8: 124-128.

SALOMÃo RP, VIEIRA IMG, SUEMITSU C, RosA NA, ALMEIDA SS, AMARAL DD AND MENEZES MPM. 2007. As florestas de Belo Monte na grande curva do rio Xingu, Amazônia Oriental. Bol Mus Para Emílio Goeldi Ciências Naturais 2(3): 57-153.

SILVA GG, LIMA MIC, ANDRADE ARF, ISSLER RS AND GUIMARÃES G. 1974. Geologia das folhas SB.22 Araguaia e Parte de SC.22 Tocantins. In: Programa de Integração Nacional, Levantamento de Recursos Naturais. Vol. 4, Rio de Janeiro: DNPM, Projeto RADAM, p. 91-143.

TUNDISI JG. 2007. Exploração do potencial hidrelétrico da Amazônia. Estud av 21(59): 109-117.

VANE-Wright RI, Humphries CJ AND WiLliams PH. 1991. What to protect? Systematics and the agony of choice. Biol Conser 55: 235-254.

VELOSO HP, RANGEL FAL AND LiMA JCA. 1991. Classificação da vegetação brasileira adaptada ao sistema universal, Rio de Janeiro: IBGE, 124 p.

WitTMAnN F, Junk WJ AND PIEDAdE MTF. 2004. The várzea forests in Amazonia: Flooding and the highly dynamic geomorphology interact with natural forest succession. Forest Ecol Manag 196: 199-212.

WitTMAnN F, JUnK WJ AND Schongart J. 2010. Phytogeography, species diversity, community structure and dynamics of central Amazonian floodplain forests. In: Junk WJ et al. (Eds), Central Amazonian Floodplain Forests: Ecophysiology, Biodiversity and Sustainable Management, Ecological Studies, Springer Verlag, p. 61-102.

ZAR JH. 2010. Biostatistical Analysis, $5^{\text {th }}$ ed., New Jersey: Prentice-Hall, Englewood Cliffs, 944 p. 